\title{
Implication of Meteorological Parameters on the Incidence of Purple Blotch of Onion under Odisha Condition
}

\author{
B. Khamari ${ }^{*}$, A. Roy $^{2}$ and A. Sushree ${ }^{1}$ \\ ${ }^{1}$ Department of Plant Pathology, Orissa University of Agriculture and Technology, \\ Bhubaneswar- 751003, Odisha, India \\ ${ }^{2}$ Department of Fruit Science and Technology, Orissa University of Agriculture and Technology, \\ Bhubaneswar- 751003, Odisha, India \\ *Corresponding author
}

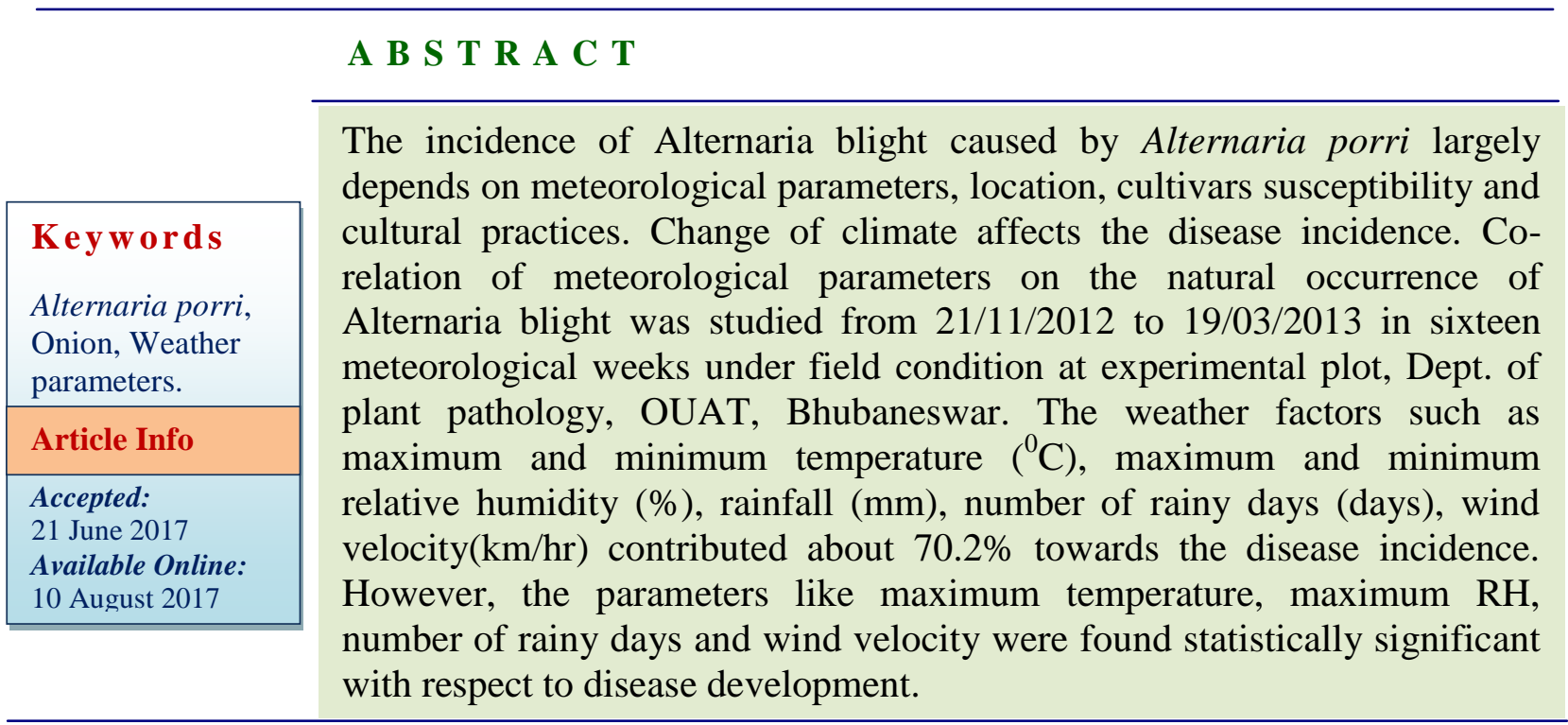

\section{Introduction}

Onion (Allium cepa) is a popular vegetable crop grown in India. It is an important source of vitamins, minerals and proteins. Onion is found to be effective against heart diseases and other ailments like treatment of anaemia, urinary disorder, bleeding piles and teeth disorders (Lokhande et al., 2011). Onions are among the most widely adapted vegetable crops. They can be grown from the tropics to sub-arctic regions. But it succeeds best in mild season without extremes of heat and cold. Indian onions have two crop cycles, first harvesting starts in November to January and the second harvesting from January to May. India is the $2^{\text {nd }}$ largest producer of onion in the world after China. There is a lot of demand of Indian Onion in the world, the country has exported 1.48 million Tonnes of fresh onion to the world for the worth of Rs. $3,169.63$ crores during the year 2013-14.

Major Export Destinations (2013-14) are Bangladesh, Malaysia, Sri Lanka, United Arab Emirates, Indonesia, Pakistan and Singapore. The Major Onion producing states area Maharashtra, Karnataka, Madhya 
Pradesh, Gujarat, Bihar, Andhra Pradesh, Rajasthan, Haryana and Tamil Nadu. Maharashtra ranks first in Onion production with a share of $27.72 \%$. Being the eleventh highest producer of onion, Odisha produces 4.1 lakhs tonnes in 2012-13(National Horticulture Board).

Various factors are responsible for low yield of the crop, especially disease. Onion is susceptible to numerous foliar, bulb and root pathogens that ultimately reduce yield and quality.

Onion is subjected to the attack by several fungal, bacterial and viral diseases. Onion diseases can cause severe losses by reducing yield and quality of marketable onions.

These onion diseases can occur in seedbeds, production fields and storage. Among all, purple blotch incited by Alternaria porri causes huge economic loss. The incidence of Alternaria blight caused by Alternaria porri largely depends on meteorological parameters, location, cultivars susceptibility and cultural practices.

Change of climate affects the disease incidence. For that present investigation was taken to study on the disease incidence in relation with the weather parameters.

\section{Materials and Methods}

In order to study the relationship of meteorological parameters on the natural occurance of Alternaria leaf blight disease onion cultivar Agrifound dark red was selected. Five randomly selected samples each comprising of 10 plants were taken for observation at weekly intervals from 21/11/2012 to $19 / 03 / 2013$ consisting of 17 meteorological weeks, 2012-13 (Rabi) under field condition at experimental field, Department of Plant Pathology, OUAT, Bhubaneswar.
Intensity of disease appearance on onion leaves was followed through visual estimation. Per cent disease incidence (PDI) was calculated by using the formulae as mentioned below

PDI $=\frac{\text { Sum of all numerical ratings } \times 100}{\text { Total no. of observations } \times \text { Maximum disease rating }}$

For recording the disease incidence of the test samples, the standard scale (0-6) was followed (Conn et al., 1990) as indicated below.

Standard meteorological parameters like maximum and minimum temperature $\left({ }^{\circ} \mathrm{C}\right)$, morning and afternoon $\mathrm{RH}(\%)$, rain fall $(\mathrm{mm})$ and wind velocity $(\mathrm{km} / \mathrm{hr})$ were obtained from the meterological observatory, Department of Agronomy, OUAT, Bhubaneswar. Simple correlation, regression and per cent contribution of weekly average meteorological parameters with disease incidence was studied for perpetuation of the disease under natural condition.

\section{Results and Discussion}

The data on meteorological parameters and disease intensity are presented in table 2 . It may be seen from the table 2 that, the disease appeared more or less throughout the season on onion leaves. There was least infection during Nov to Dec when the temperature and $\mathrm{RH}$ were in the range of $16.7^{\circ} \mathrm{C}$ to $33.1^{\circ} \mathrm{C}$ and $46-96 \%$ respectively. Disease incidence progresses towards the end of the season (Tables 1-3). The prediction equation obtained by regression analysis was

$\mathrm{Y}=-113.265+8.589 \mathrm{X}_{1}-5.964 \mathrm{X}_{2}$ $+0.396 \mathrm{X}_{3}-0.489 \mathrm{X}_{4}-0.395 \mathrm{X}_{5}+2.562 \mathrm{X}_{6}$

$+5.702 X_{7}$

Coefficient of Determination $\mathrm{R}^{2}=0.832$, Adjusted $\mathrm{R}^{2}=0.702$, Multiple Regressions: 0.912

Where, $\mathrm{X}_{1}$ : Maximum temperature, $\mathrm{X}_{2}$ : Minimum 
temperature, $\quad \mathrm{X}_{3}: \quad$ Morning $\mathrm{RH}, \quad \mathrm{X}_{4}$ : of Rainy days, $\mathrm{X}_{7}$ : Wind velocity, Afternoon $\mathrm{RH}, \mathrm{X}_{5}$ : Rainfall, $\mathrm{X}_{6}$ : Numbers $\quad \mathrm{Y}$ : Percent Disease Incidence

Table.1 Scale showing disease severity and disease incidence of Alternaria porri

\begin{tabular}{|c|c|l|l|}
\hline Sl. No. & Scale(0-6) & Disease severity & Disease incidence \\
\hline 1 & 0 & Immune & No incidence \\
\hline 2 & 1 & Highly resistant & $1-5 \%$ incidence \\
\hline 3 & 2 & Resistant & $6-10 \%$ incidence \\
\hline 4 & 3 & Moderately resistant & $11-25 \%$ incidence \\
\hline 5 & 4 & Moderately susceptible & $26-50 \%$ incidence \\
\hline 6 & 5 & Susceptible & $51-75 \%$ incidence \\
\hline 7 & 6 & Highly susceptible & $>75 \%$ incidence \\
\hline
\end{tabular}

Table.2 Weather parameters on incidence of purple blotch of onion

\begin{tabular}{|l|c|c|c|c|c|c|c|c|}
\hline $\begin{array}{l}\text { Meteorological } \\
\text { Week }\end{array}$ & $\begin{array}{l}\text { Max. } \\
\text { Temp. } \\
\left({ }^{\circ} \mathbf{C}\right)\end{array}$ & $\begin{array}{l}\text { Min. } \\
\text { temp. } \\
\left({ }^{\circ} \mathbf{C}\right)\end{array}$ & $\begin{array}{l}\text { Max. } \\
\text { RH } \\
(\boldsymbol{\%})\end{array}$ & $\begin{array}{l}\text { Min. } \\
\text { RH } \\
(\boldsymbol{\%})\end{array}$ & $\begin{array}{l}\text { Rainfall } \\
(\mathbf{m m})\end{array}$ & $\begin{array}{l}\text { No. of } \\
\text { rainy } \\
\text { days }\end{array}$ & $\begin{array}{l}\text { Wind } \\
\text { velocity } \\
(\mathbf{k m} / \mathbf{h r})\end{array}$ & PDI \\
\hline $21.11 .2012-27.11 .2012$ & 33.1 & 20.9 & 59 & 92 & 110.5 & 3.0 & 2.5 & $1.5(7.03)$ \\
\hline $28.11 .2012-04.12 .2012$ & 30.7 & 20.5 & 72 & 90 & 45.4 & 2.0 & 3.5 & $2.8(9.63)$ \\
\hline $05.12 .2012-11.12 .2012$ & 29.6 & 21.0 & 72 & 96 & 0.0 & 0.0 & 2.5 & $4.7(12.52)$ \\
\hline $12.12 .2012-18.12 .2012$ & 28.9 & 16.7 & 46 & 96 & 0.0 & 0.0 & 3.8 & $10.8(19.19)$ \\
\hline $19.12 .2012-25.12 .2012$ & 30.4 & 20.4 & 62 & 91 & 0.0 & 0.0 & 4.0 & $18.6(25.56)$ \\
\hline $26.12 .2012-01.01 .2013$ & 29.8 & 15.4 & 45 & 94 & 0.0 & 0.0 & 2.0 & $21.4(27.56)$ \\
\hline $02.01 .2013-08.01 .2013$ & 30.9 & 15.1 & 41 & 95 & 0.0 & 0.0 & 1.8 & $30.3(33.4)$ \\
\hline $09.01 .2013-15.01 .2013$ & 32.1 & 20.2 & 54 & 96 & 0.0 & 0.0 & 2.4 & $38.6(38.41)$ \\
\hline $16.01 .2013-23.01 .2013$ & 29.7 & 14.7 & 38 & 90 & 0.0 & 0.0 & 2.5 & $46.5(42.99)$ \\
\hline $23.01 .2013-29.01 .2013$ & 27.4 & 12.0 & 44 & 92 & 0.0 & 0.0 & 2.8 & $48.3(44.03)$ \\
\hline $30.01 .2013-05.02 .2013$ & 29.6 & 18.2 & 63 & 96 & 0.0 & 0.0 & 3.8 & $48.6(44.2)$ \\
\hline $06.02 .2013-12.02 .2013$ & 28.2 & 12.6 & 34 & 86 & 0.0 & 0.0 & 3.7 & $52.0(46.15)$ \\
\hline $13.02 .2013-19.02 .2013$ & 31.9 & 16.5 & 43 & 95 & 0.0 & 0.0 & 3.6 & $56.3(48.62)$ \\
\hline $20.02 .2013-26.02 .2013$ & 29.3 & 13.9 & 36 & 88 & 0.0 & 0.0 & 3.6 & $58.6(49.95)$ \\
\hline $27.02 .2013-05.03 .2013$ & 29.9 & 14.4 & 41 & 94 & 0.0 & 0.0 & 3.5 & $58.6(49.95)$ \\
\hline $06.03 .2013-12.03 .2013$ & 32.5 & 16.8 & 36 & 88 & 0.0 & 0.0 & 2.5 & $60.0(50.77)$ \\
\hline $13.03 .2013-19.03 .2013$ & 31.6 & 17.4 & 40 & 90 & 2.8 & 2.0 & 2.9 & $60.0(50.77)$ \\
\hline
\end{tabular}

Figure in paranthesis indicates the transform value

Table.3 Co-relation Matrix of climatic parameters on disease incidence (Rabi, 2012-2013)

\begin{tabular}{|c|c|c|c|c|c|c|c|c|}
\hline & $X 1$ & $X 2$ & $X 3$ & $X 4$ & $X 5$ & $X 6$ & $X 7$ & $Y$ \\
\hline $\mathrm{X} 1$ & 1.000 & & & & & & & \\
\hline $\mathrm{X} 2$ & 0.596 & 1.000 & & & & & & \\
\hline X3 & 0.136 & 0.826 & 1.000 & & & & & \\
\hline $\mathrm{X} 4$ & 0.076 & 0.329 & 0.408 & 1.000 & & & & \\
\hline$\times 5$ & 0.467 & 0.459 & 0.385 & -0.097 & 1.000 & & & \\
\hline X6 & 0.499 & 0.461 & 0.323 & -0.206 & 0.853 & 1.000 & & \\
\hline $\mathrm{X} 7$ & -0.312 & -0.012 & 0.111 & -0.173 & -0.116 & -0.082 & 1.000 & \\
\hline $\mathrm{Y}$ & -0.125 & -0.657 & -0.743 & -0.286 & -0.608 & -0.454 & 0.128 & 1.000 \\
\hline
\end{tabular}


Table.4 Per cent contribution of individual parameters to disease incidence

\begin{tabular}{|l|l|c|}
\hline & \multicolumn{1}{|c|}{ Parameters } & per cent contribution to disease incidence \\
\hline $\mathrm{X}_{1}$ & Maximum temperature & 49.52 \\
\hline $\mathrm{X}_{2}$ & Minimum temperature & 23.88 \\
\hline $\mathrm{X}_{3}$ & Morning RH & 0.11 \\
\hline $\mathrm{X}_{4}$ & Afternoon $\mathrm{RH}$ & 0.16 \\
\hline $\mathrm{X}_{5}$ & Rainfall & 0.11 \\
\hline $\mathrm{X}_{6}$ & Numbers of Rainy days & 4.41 \\
\hline $\mathrm{X}_{7}$ & Wind velocity & 21.82 \\
\hline
\end{tabular}

The weather parameters like maximum and minimum temperature, maximum and minimum RH, rainfall, number of rainy days and wind velocity in total contributed about $70.2 \%$ towards the disease development. However, maximum temperature, maximum $\mathrm{RH}$, number of rainy days and wind velocity were found to be statistically significant with respect to disease development which supports the findings of Cova and Rodriguez (2001), Delahaut and Walt (2004) and Shrestha et al., (2005) (Table 4). The maximum temperature alone contributed $49.28 \%$ towards the disease development followed by minimum temperature $(23.88 \%)$ and then wind velocity $(21.82 \%)$. Razdan $e t$ al., (2012) found maximum temperature, maximum $\mathrm{RH}$ and rainfall influence the disease incidence which is corroboration with present findings. Weather parameters play a vital role in causing disease incidence.

\section{References}

Conn, K.L., Tiwari, J.P. and Aswasthi, R.P.1990. A disease assessment key for
Alternaria black spot in rapeseed and mustard. Canadian plant disease survey. 70:19-22.

Cova, J. and Rodriguez, D. 2001. Effect of temperature and relative humidity on leaf blight on onion (Allium cepa L.). Proceedings of the Inter American Society for Tropical Horticulture, 45:95-97.

Lokhande T.N, Barakade A.J. and Todkari G.U. 2011. Economics of onion cultivation and its marketing pattern in Satara district of Maharashtra. International Journal of Agricultural Sciences, 3(3):110-117.

National Horticulture Board (NHB), 2012-13.

Razdan, V.K., Shahnaz, E. and Kumar, S. 2012. Influence of weather parameters on purple blotch of onion. Indian phytopathology, 61(1):557-559.

Shrestha S.K., Munk, L. and Mathur S.B. 2005. Role of weather on Alternaria leaf blight disease and its effect on yield $\&$ yield components of mustard. Nepal Agric. Res. J, 6: 27.

\section{How to cite this article:}

Khamari, B., A. Roy and Sushree, A. 2017. Implication of Meteorological Parameters on the Incidence of Purple Blotch of Onion under Odisha Condition. Int.J.Curr.Microbiol.App.Sci. 6(8): 2643-2646. doi: https://doi.org/10.20546/ijcmas.2017.608.314 